\title{
The Audit Reform and Non-Audit Services in the Light of the Big-4 Transparency Reports - the EU Perspective
}

\author{
Magdalena Indyk ${ }^{1}$ \\ ${ }^{1}$ Independent Researcher, ACCA, ORCID: 0000-0001-9141-162X \\ Correspondence: Magdalena Indyk,E-mail: mag.indyk@gmail.com
}

Received: October 7, 2020

Accepted: November 11, 2020

Available online: November 20, 2020

doi:10.11114/aef.v8i1.5084

URL: https://doi.org/10.11114/aef.v8i1.5084

\begin{abstract}
The aim of this article is to compare and contrast three different approaches towards non-audit services (henceforth "NAS") based on: 1) researchers' views, 2) the EU regulation, and 3) the provision of NAS by the Big-4 firms operating in twenty-seven EU member states. Therefore, the article includes: (i) a literature review of various NAS aspects, (ii) an analysis of the EU reform in terms of NAS, and (iii) an empirical analysis of NAS fees which have been disclosed in the Big-4 transparency reports for the period 2017-2019.

The literature review shows: a) lack of consensus between researchers about the potential consequences of the NAS provision in general, b) quite limited or little evidence of the consequences of the NAS restrictions as part of the EU audit reform, c) ambiguity in terms of the NAS definition itself which results mainly from insufficient NAS disclosures and lack of a detailed NAS split.

The EU regulators addressed these concerns only in very narrow aspects, i.e., through: (1) the NAS black list, (2) the NAS cap, and (3) the strong emphasis on public-interest entities (henceforth "PIEs"). What is more, NAS disclosure requirements in the transparency reports are limited only to two categories.

Finally, the results of the empirical study indicate the significant differences at the NAS fee level among the EU member states. The analysis shows a particular importance of NAS fees from other clients as a substantial revenue stream for the Big-4 firms. The results suggest also a significant increase in this category in 2018 when NAS fees from other clients increased by net EUR809 million (13\%). However, this strong trend was not confirmed in the following year.

All in all, the study underlines deficiency in proper NAS disclosure and reporting which might be observed also in the case of transparency reports. All findings of this study may be another argument for regulators to address the problem of NAS in more detail starting from their advice on a NAS taxonomy which might be used then as a point of reference. It would be also beneficial for researchers exploring the NAS aspect and, thus, may enhance data and results comparability between studies. Additional disclosure requirements like NAS provided to PIEs or a recurring or non-recurring character of NAS would also support the better understanding and evaluation of the consequences of the EU audit reform.
\end{abstract}

Keywords: non-audit services, non-audit fees, audit reform, Big-4

JEL codes: M42, M48

\section{Introduction}

The EU audit reform, implemented through the EU Directive 2014/56/EU (2014) and the EU Regulation 537/2014 (2014), is a good example how powerful the law might be. It is a phenomenon to enforce the law in the whole union which consists of twenty-seven totally different countries taking into account their culture, development, jurisdiction, and regulations already existing at a national level. The general aim of such "one size fits all" approach is an attempt to harmonise and standardise activities and behaviour among the EU member states.

In order to re-build public trust towards the audit profession, the EU regulators decided to focus on the auditor independence and to eliminate the major factors posing a potential threat. Therefore, not surprisingly, the key points of the EU audit reform were: (i) mandatory audit rotation, and (ii) general prohibition of NAS. The former aims to reduce a possible familiarity threat and to avoid potential erosion of professional scepticism due to too long audit engagements 
while the latter is believed to enhance the auditor independence and to prevent audit firms from financial over-reliance on one particular audit client.

The aim of this study is to evaluate NAS based on:

1) the concerns raised by researchers;

2) the response from the EU regulators in a form of the audit reform; and

3) the analysis of the aggregate NAS fees disclosed in the transparency reports published by the Big-4 firms across all twenty-seven EU member states in the period 2017-2019.

In order to examine these aspects, three steps have been adopted. Firstly, a literature review aiming to capture the main points addressed by researchers in terms of NAS. Secondly, it was contrasted with the solutions proposed by the regulators. Finally, an analysis of NAS fees, included in the transparency reports, provided an empirical evidence to the whole discussion.

In total, 315 transparency reports, covering the period 2017-2019, have been collected from the websites of the Big-4 firms, i.e., Deloitte, EY, KPMG, and PWC operating in each EU member state. The total expected number of transparency reports was $324^{1}$, however, nine reports were not available. The Big-4 group has been chosen because of their size and a dominant position on the audit market globally. In terms of changes in trends, they may also act as a "tone from the top" for the whole profession.

There are several findings of this paper. First of all, it should be underlined that there are three parties, i.e., the Big-4 firms, regulators, and researchers, who look at NAS in a different way and with different intentions. For the Big-4 group NAS are primarily a great revenue stream and it seems they continue their way to offer such services but to clients other than audited ones. Researchers treat NAS as one of the major threats to the auditor independence and focus on further possible implications in this term. Finally, regulators have this power to impose and execute law and, therefore, they generally prohibited the provision of NAS but only with regard to public interest entities. As the intentions of all three parties and their approach towards NAS overlap only in a very small part, the audit reform seems not to be perfect in its construction.

The paper specifically indicates very poor NAS reporting requirements, including lack of the formal NAS taxonomy of permitted services. The current NAS disclosure requirements include only two categories in transparency reports (i.e., NAS fees from audit clients and NAS fees from other clients) and do not consider even a separate category for PIEs.

Empirical research, carried out on the basis of NAS fees collected from transparency reports, provides the overall view of NAS fees across the EU member states and shows the significant differences at the NAS fee level among them which may be associated with the particular country's economic potential and its development. What is more, NAS fees from other clients seem to be a substantial revenue stream for the Big-4 firms which may mean that they are looking for a kind of compensation for imposed prohibitions but it may also indicate an existing demand for specific financial services which the Big-4 firms can simply fulfil. Additionally, the area of NAS for other clients, as being outside the main discussion on statutory audit, seems not to belong to the regulators' primary interest.

The remainder of this paper is organised as follows. Sections 2-4 present the results of the literature review in various NAS aspects, whereas Section 5 shows the regulators' view on NAS. Section 6 includes the results of the empirical analysis. The last Section presents conclusions.

\section{Literature Review}

\subsection{NAS and the Auditor Independence}

It is not surprising to see that a huge number of research papers addresses a potential impact of NAS on the auditor independence. In the lively discussion lasting over twenty-five years, there is a repeatedly arising belief among researchers that offering NAS to audit clients leads to over-reliance on one revenue stream which may result in the auditor independence being compromised. If so, auditors would be financially motivated to support client's interest rather than to maintain their professional scepticism. Therefore, different researchers make an attempt to verify whether this statement is true or not.

Some researchers use an approach which bases on questionnaires or interviews with different groups involved in an audit such as: auditors, CEOs, finance directors, managers, internal auditors, audit committees, etc. These studies clearly show that independence and influence of NAS is a matter of perception and differs among respondents and countries. Therefore, the results are rather mixed and do not provide a single conclusion. There are studies confirming the perceived negative impact of NAS (e.g., Flaming, 2002, Salehi and Moradi, 2010, Meuwissen and Quick, 2019),

\footnotetext{
${ }^{1}$ (four firms) x (twenty-seven countries) $\mathrm{x}$ (three years)
} 
studies presenting generally the opposite view (e.g., Obeid, Obeid, and Sundarasen, 2017) and studies showing mixed results (e.g., Ramzan, Ahmed, and Rafay, 2020; Al-Ajmi and Saudagaran, 2011).

A group of studies associate the auditor independence with the auditors' propensity to issue going concern or qualified audit opinions. It is commonly believed that offering NAS may violate auditors' professional behaviour and may lead to auditors being not willing to issue an unfavourable audit opinion. As a confirmation, Legoria, Rosa, and Soileau (2017) suggest that audit clients purchasing nil NAS or NAS being less than Sarbanes-Oxley's benchmark (accounting for $5 \%$ of total fees), are more likely to receive a material weakness opinion than clients with a higher volume of purchased NAS. Ahmad, Shafie, and Yusof (2006) suggest a positive relationship between audit fees and NAS and a significant relationship between NAS and qualified audit opinions which altogether indicates a significant threat to the auditor independence. However, Craswell (1999) does not confirm the relationship between qualified opinions and the provision of NAS. Similarly, DeFond, Raghunandan, and Subramanyam (2002) and Read (2015) find no significant relation between going-concern decisions and both audit and NAS fees.

\subsection{NAS and Audit Quality}

The provision of NAS is not only associated with the impairment of the auditor independence but it is also considered as a potential factor leading to the lower audit quality measured often by earnings or accruals quality. The researchers usually follow the reasoning that the potential impairment of auditor independence (being a result of high NAS fees) would lead to lower audit quality as auditors would be more interested in maintaining a positive relationship with an audit client. Again, research studies provide mixed results (Tepalagul and Lin, 2015). As an example, the results of a study carried out by Effiezal Aswadi Abdul, Nik Abdul Majid, Harymawan, and Agustia (2020) suggest a negative impact of NAS on accruals quality. Similarly, Hohenfels and Quick (2020) generally indicate a negative influence of NAS on audit quality (except from tax services which do not confirm this relationship). According to Ianniello (2015), NAS appear to be positively associated with the absolute abnormal working capital accruals which suggests a lower quality of earnings. On the other hand, Garcia-Blandon, Argiles and Ravenda (2020) present an opposite view and do not confirm a significant relationship between NAS and audit quality. Similarly, Carmona, Momparler, and Lassala (2015) suggest that audit and financial reporting quality are uncompromised by the provision of NAS fees. Bell, Causholli, and Knechel (2015) do not find an association, on average, between total NAS fees and audit quality in the full sample (however, they observe a positive association with quality for SEC registrants and a negative association with quality for privately held clients).

Another important aspect is so called knowledge spillover. A common argument for NAS is the expected value added for an audit client if the same audit firm provides multiple services. Wahab, Gist and Majid (2014) suggest a positive influence of recurring NAS on knowledge spillover leading to the enhancing of audit and financial reporting quality. Knowledge spillover is also partially confirmed by De Fuentes and Pucheta-Martinez (2009). As another positive aspect of NAS, Walker and Hay (2013) suggest the relationship between NAS and a shorter audit report lag, which is not observed immediately but in a subsequent period.

\subsection{NAS and Other Audit or Accounting Features}

Some researchers investigate the NAS relationship with the selected auditor's features like auditor's tenure. For example, Al-Hajri (2018) indicates a negative relationship between the joint provision of NAS and external audit firm's tenure. Bamahros and Wan-Hussin (2015) suggest that longer audit tenure reduces earnings management but at the same time the provision of NAS exacerbates it.

Having a control over NAS might be also perceived as an important attribute of audit client's corporate governance. Some authors underline the importance of an effective audit committee in this term (e.g., Al-Sraheen, 2019, Ali, Singh, and Al-Akra, 2018). Wu, Hsu, and Haslam (2016) suggest the association between NAS, auditors' reporting decisions and the composition of an audit committee (i.e., the presence of non-executive directors and financial experts).

\section{NAS and the Implications of the Audit Regulations}

The literature review presented above shows that a discussion about NAS is multi-dimensional and researchers have not reached a conclusion yet about the consequences if such services are provided. Despite this inconclusiveness, the EU regulators decided to turn the theoretical assumptions into the real law which at the same time has led to the creation of two sub-periods: pre- and post-regulation.

The formal attempts to regulate the audit profession are, however, not new and occurred earlier in the past. In the US, there is a flagship example of the Sarbanes-Oxley Act (henceforth "SOX") which was enacted in 2002 and which introduced the new era of "after-SOX" research studies. Discussing the impact of the acts like SOX, we need to be aware that this is a conjunction of different means which together aim to enhance the auditor independence and audit quality. In the case of SOX, the act assumed a) the establishment of the Public Company Accounting Oversight Board (henceforth "PCAOB"), b) strengthened supervision over auditors/audit firms and their independence (including NAS 
limitations), c) a more powerful role of audit committees, d) strengthened corporate governance and internal control of the audit clients (i.e., public companies), e) enhanced financial disclosures, and f) more stringent crime penalties (the SOX, 2002). Therefore, NAS are only one of the building blocks in the whole construction.

Based on SOX example, the researchers keep evaluating the influence of its particular elements. NAS are also widely examined and discussed. Anandarajan, Kleinman and Palmon (2012) explore whether NAS are a suitable proxy for the auditor independence after the SOX implementation, taking into account that NAS have been restricted by the act. The results of their study suggest that pre-SOX studies delivered more significant outcomes and results than post-SOX ones. Chu and Hsu (2018) investigate the pre- and post-SOX impact of NAS on the audit quality measured by accounting conservatism. The empirical results of their study indicate poorer audit quality pre-SOX and no conclusive results in the post-SOX group, suggesting an overall positive influence of the act itself. Similarly, Lisic, Myers, Pawlewicz, and Seidel (2019) suggest a negative impact of high consulting revenues on audit quality in the pre-SOX period with no statistically significant association in the post-SOX period. On the other hand, Kohlbeck, Brown, and Trainor (2010) provide evidence of negative effects from the prohibition of NAS, including concerns about the loss of knowledge spillover effects.

Similarly to SOX, the audit reform in Europe consists of several parts including: a) mandatory audit rotation in the case of audits carried out in PIEs, b) general prohibition of NAS, c) tightened supervision over auditors/audit firms, and d) increased importance of audit committees (the EU Regulation, 2014). It is also expected that researchers will concentrate on the particular building blocks of the reform.

Apart from the generally discussed aspects of the auditor independence and audit quality, the formal EU proposal of the NAS restrictions encountered some initial arguments against it. For example, Bleibtreu and Stefani (2012) suggest as a potential consequence of the NAS restrictions a decrease in the equilibrium number of audit firms (in other words an increase in market concentration) and even negative effects on the quality of audited financial statements. Ratzinger-Sakel and Schönberger (2015) compare the EU regulation with the national requirements in France, Germany and the UK, focus on the NAS cap and the blacklist approach, and provide their justification why the reform might not be successful in its design.

Unfortunately, there are only few research studies which target at the NAS and the post-regulation consequences. Meuwissen and Quick (2019) confirm in their article the general rationale behind the NAS restrictions and suggest a perceived negative effect of the NAS on the auditor independence based on the opinion of the German supervisory board members. Van Liempd, Quick and Warming-Rasmussen (2019) provide the post-EU-regulation evidence from Denmark and confirm negative perception of the NAS provision towards the auditor independence. Clacher, de Ricquebourg and May (2019), based on the UK experience, underline the need for the revisiting of the PIE definition. Aschauer and Quick (2018) suggest that both audit-firm rotation and the prohibition of tax services are perceived as beneficial but the joint implementation leads to no additional benefits.

Among researchers making an attempt to quantify the effects of the audit reform it is worth mentioning Horton, Tsipouridou and Wood (2018). The authors find that investors reacted positively to the EU proposals, lifting the aggregate market value by approx. EUR108,630 million. The authors find also that investors reacted positively and significantly to NAS restrictions and a cap. Hohenfels and Quick (2020) refer to the specificity of the German setting rather than to the EU Regulation itself and concentrate on the pre-regulation period between 2006 and 2013 suggesting that higher levels of NAS negatively affect audit quality. Finally, Castillo-Merino, Garcia-Blandon and Martinez-Blasco (2018) explore the potential impact of future audit-related, tax and other services on audit quality based on the data for the period 2005-2016. The authors find no significant results in the case of audit-related and tax services whereas confirm a consistent negative association between future NAS fees in the "other" category and audit quality.

The European Parliament's Committee on Economic and Monetary Affairs requested an in-depth analysis aiming to evaluate the initial consequences of the audit reform (Willekens, Dekeyser and Simac, 2019). The report addresses different aspects of the reform, including its impact on the audit fees, audit market structure, audit quality and NAS. In terms of NAS, the authors examine how the nominal level of NAS fees evolved over the period 2013-2017. They find that the average NAS fee has decreased by $31 \%$ for the Big- 4 group and by $9 \%$ for the non-Big- 4 firms.

Taking into account that: a) various researchers confirm changes as a result of a legal act enactment, b) there is currently a very little evidence about the measurable consequences of the EU Regulation, and c) ten out of twenty-seven member states implemented the Regulation by June 2016, fifteen by June 2017 and one later (Accountancy Europe, 2019), the following hypothesis has been defined:

$[\mathrm{H}]$ The implementation of the $\mathrm{EU}$ audit reform resulted in some nominal changes in NAS fees in the period 2017-2019 among the EU member states.

In order to verify the hypothesis, the following sub-questions have been asked and explored: 
Sub-question 1: How are NAS defined and interpreted among researchers? (section 4)

Sub-question 2: How did the EU regulators address the problem of NAS? (section 5);

Sub-question 3: What can be concluded from the empirical analysis of the NAS financial data published in the transparency reports? (section 6).

\section{Definition of NAS and the Importance of Their Disclosure}

The visible ambiguity relates to different audit and non-audit services being mixed up. There is no unified understanding of NAS and a formal taxonomy of permitted services does not exist. It leads to multiple studies presenting different approaches towards NAS. Some researchers examine NAS as one group of non-statutory audit services or consulting services (e.g., Firth, 1997, Patel, Varma, and Prasad, 2009). There are researchers who consider specifically tax services (e.g., Aschauer and Quick, 2018, Kwak and Park, 2020). Another group of researchers distinguishes three basic NAS categories: audit-related, tax, and other services (e.g., Ianniello, 2011; Wahab, Gist and Majid, 2014). On the other hand, Ezzamel, Gwilliam, and Holland (2002) explore five NAS types: accounting-related, finance advice, tax services, management consultancy, and other non-audit services. Finally, some researchers make an attempt to evaluate specific NAS, for example, Meuwissen and Quick (2019) concentrate on tax, financial information system and HR consulting. Sori, Karbhari and Mohamad (2010) consider fifteen types of NAS whereas van Liempd, Quick and Warming-Rasmussen (2019) more than thirty.

The differences in approach towards NAS are dictated mainly by data source limitations, lack of unified requirements in terms of NAS reporting and the specificity of each research study. In order to show that a detailed decomposition of NAS would be beneficial, let us think about the services an auditor is entitled to do.

The primary auditor's role is to perform a statutory audit which is an audit of annual financial statements and consolidated financial statements (the EU Directive, Article 2.1.). However, it is not the only service an auditor can provide within his or her duties. Another important service is a review of a financial statement. Companies listed on the stock exchange may be required to report audited interim condensed financial statements and such financial statements are not literally subject to an audit but to a review. The aim, scope and procedures of a review are specified in separate standards, like ISRE 2400. The third group of services, which might be provided by auditors, are attestation engagements (other than audits or reviews) and are regulated by dedicated standards, e.g., ISAE 3000. Such engagements aim to obtain sufficient and appropriate evidence in order to express conclusion about the subject matter information and to enhance the degree of confidence of the intended users (ISAE 3000, point 12(a)).

All other services represent advisory activities which are different in terms of their nature and the methodology used. What is more, their final impact on the financial statement may also be different. Therefore, there is a strong need to distinguish and explore specific types of NAS and their potential impact on the auditor independence and the audit cycle itself.

The ambiguity around NAS results not only from differences in the NAS definition but subsequently from the discrepancies between NAS disclosure requirements and data availability. Beattie and Fearnley (2002) underline in their literature review a problem of lack of publicly available data of relevance, i.e., the problem of NAS fees being published at the aggregate level without a split across service types. Additionally, they point out that the audit firms themselves, at the time of their study, did not reveal such information.

The need for better NAS reporting includes a need for mandatory rules, disclosure within meaningful categories and consideration whether NAS are provided on a recurring or non-recurring basis (Ahmad, Shafie and Yusof, 2006). Some researchers underline benefits from NAS disclosures. According to Sori, Karbhari and Mohamad (2010), full disclosure of the NAS provision in the client's financial statement may act as a safeguard towards the auditor independence as it would inform shareholders and regulators about the auditor's involvement. Iyer, Iyer and Mishra (2003) find significant differences in the level of NAS and in the ratio of NAS fees to audit fees between companies that voluntarily disclosed NAS fees in 1991 and companies which did not. On the contrary, the results of the study performed by Lennox (1999) do not support the view that voluntary disclosure of NAS was used to signal audit quality.

\section{The EU Regulators' Response to the Concerns Related to Non-Audit Services}

The EU regulators made an attempt to address the concerns regarding NAS. The first aspect of the EU regulation, which should be primarily discussed, is the fact that the EU reform concentrates only on PIEs and on statutory audits of their financial statements.

The EU Directive (2014, Article 2.13) classifies various entities as PIEs: entities whose transferable securities are admitted to trading on a regulated market, credit institutions, insurance undertakings, and entities designated by the EU member states as PIEs. Consequently, the EU regulators divided audits and audit clients into two groups: PIEs and Non-PIEs and decided that all the efforts should concentrate on the first group. Theoretically, there is a logic behind 
such approach. As it is impossible to supervise the whole audit market, the regulators decided to determine the audits of the highest influence, i.e., audits carried out in the entities generally treated as the most significant for the public interest due to their nature.

As discussed earlier, as audit firms tended to provide different kinds of NAS to the significant extent in the past, it raised concerns about their potential implications to the auditor independence. Therefore, in order to address and solve this problem, the EU Regulation (2014, Article 5) provides a list of the following NAS which are currently prohibited if a statutory audit is carried out in PIEs:

- tax services;

- $\quad$ services involving participation in management or decision-making processes;

- bookkeeping, preparation of accounts and financial statements;

- payroll services;

- design and implementation of internal control or risk management procedures;

- valuation services;

- legal services;

- services related to the internal audit function;

- services related to the financing, capital structure and allocation, and investment strategy;

- promoting, dealing or underwriting shares;

- human resources services.

Twenty-four member states decided to apply the above list, one member state (France) introduced additional prohibitions and two countries (Poland and the Netherlands) applied a "white list" approach which means that the only allowed NAS are those included in a "white list" (Accountancy Europe, 2018, p.7). However, the EU regulators considered derogation. Auditors may offer some tax and valuation services ${ }^{2}$ only if they have no direct impact on the financial statement (or the impact is immaterial), the estimation of the effect is documented and explained in the additional report to the audit committee, and the provision of such services will not affect the auditor independence (the EU Regulation, 2014, Article 5.3.). Table 1 shows the implementation of the NAS provisions across the EU member states.

Table 1. Implementation of the NAS provision in the EU

\begin{tabular}{|c|c|c|c|c|c|c|c|}
\hline \multirow{2}{*}{$\begin{array}{l}\text { Member } \\
\text { state }\end{array}$} & \multicolumn{2}{|c|}{$\begin{array}{c}\text { Allowed } \\
\text { derogation }\end{array}$} & \multirow{2}{*}{$\begin{array}{c}\text { No } \\
\text { derogation }\end{array}$} & \multirow{2}{*}{$\begin{array}{c}\text { Member } \\
\text { state }\end{array}$} & \multicolumn{2}{|c|}{$\begin{array}{c}\text { Allowed } \\
\text { derogation }\end{array}$} & \multirow{2}{*}{$\begin{array}{c}\text { No } \\
\text { derogation }\end{array}$} \\
\hline & $\begin{array}{c}\text { Tax } \\
\text { services }\end{array}$ & $\begin{array}{l}\text { Valuation } \\
\text { services }\end{array}$ & & & $\begin{array}{c}\text { Tax } \\
\text { services }\end{array}$ & $\begin{array}{l}\text { Valuation } \\
\text { services }\end{array}$ & \\
\hline Austria & $\mathbf{x}$ & $\mathbf{x}$ & & Italy & & & $\mathbf{x}$ \\
\hline Belgium & $\mathbf{x}$ & $\mathbf{x}$ & & Latvia & $\mathbf{x}$ & $\mathbf{x}$ & \\
\hline Bulgaria & $\mathbf{x}$ & & & Lithuania & $\mathbf{x}$ & & \\
\hline Croatia & $\mathbf{x}$ & $\mathbf{x}$ & & Luxembourg & $\mathbf{x}$ & $\mathbf{x}$ & \\
\hline Cyprus & $\mathbf{x}$ & $\mathbf{x}$ & & Malta & $\mathbf{x}$ & $\mathbf{x}$ & \\
\hline Czech Rep. & $\mathbf{x}$ & $\mathbf{x}$ & & Netherlands & & & $\mathbf{x}$ \\
\hline Denmark & $\mathbf{x}$ & $\mathbf{x}$ & & Poland & & & $\mathbf{x}$ \\
\hline Estonia & $\mathbf{x}$ & $\mathbf{x}$ & & Portugal & & & $\mathbf{x}$ \\
\hline Finland & $\mathbf{x}$ & $\mathbf{x}$ & & Romania & $\mathbf{x}$ & $\mathbf{x}$ & \\
\hline France & & & $\mathbf{x}$ & Slovakia & $\mathbf{x}$ & $\mathbf{x}$ & \\
\hline Germany & $\mathbf{x}$ & $\mathbf{x}$ & & Slovenia & & & $\mathbf{x}$ \\
\hline Greece & $\mathbf{x}$ & $\mathbf{x}$ & & Spain & $\mathbf{x}$ & $\mathbf{x}$ & \\
\hline Hungary & $\mathbf{x}$ & $\mathbf{x}$ & & Sweden & $\mathbf{x}$ & $\mathbf{x}$ & \\
\hline Ireland & $\mathbf{x}$ & $\mathbf{x}$ & & & & & \\
\hline
\end{tabular}

Source: Accountancy Europe (2019, p. 11).

\footnotetext{
2 The EU regulators allowed the following tax services: preparation of tax forms, identification of public subsidies and tax incentives, support regarding tax inspections, calculation of direct, indirect and deferred tax, and tax advisory. Tax services relating to payroll tax and customs duties remains prohibited. The regulators allow derogation in terms of valuation services but do not determine details. They only mention valuations in relation to actuarial or litigation support services (the EU Regulation, 2014, Article 5.3.).
} 
As presented in Table 1, nineteen member states agreed on the potential tax and valuation services, two countries allowed only limited tax services and six countries did not allow exemptions at all. The EU reform assumes that the NAS should be limited to no more than $70 \%$ of the fees for statutory audit paid in the last three consecutive financial years (the EU Regulation, 2014, Article 4.2.) which was applied by all EU member states (the Accountancy Europe, 2019, p. 12). The NAS cap relates to the parent entity, its controlled undertakings, and to the group as a whole.

Statutory auditors and audit firms have to comply with different reporting requirements, out of which one is worth mentioning here. According to Article 13 of the EU Regulation (2014), a statutory auditor or an audit firm which carries out statutory audits of PIEs should make an annual transparency report public. A transparency report is a valuable source of information in terms of (Article 13.2, (a)-(j)): audit firm's legal structure, its ownership, firm's network, governance structure, internal quality control system, PIEs for which a statutory audit was carried out, independence, auditors' continuing education, the basis for the partners' remuneration and auditors' or audit firm's approach towards the rotation of key audit partners.

If not disclosed in the firm's financial statement, transparency report should include financial data (i.e., audit firm's total turnover) with the split into four categories (Article 13.2. (k)):

(i) revenues from the statutory audit of annual and consolidated financial statements of public-interest entities and entities belonging to a group of undertakings whose parent undertaking is a public-interest entity;

(ii) revenues from the statutory audit of annual and consolidated financial statements of other entities;

(iii) revenues from permitted non-audit services to entities that are audited by the statutory auditor or the audit firm; and

(iv) revenues from non-audit services to other entities.

Such classification, despite theoretically good intentions of regulators, might be too vague which will be discussed later in this paper based on the empirical evidence. Firstly, the regulators distinguished statutory audit as a core service and at the same time all other services as NAS. It means that groups (iii) and (iv) include potentially everything: from assurance services other than statutory audit to consulting services. It might lead to misleading conclusions as reviews or attestation services should not be treated in the same way as valuation or tax services which do not belong to core auditor's activities. Secondly, the regulators do not consider the impact of other firms in the network (e.g., some NAS might be provided by dedicated consulting firms which belong to the same network as the audit firm). Thirdly, the regulators do not require to present the amount of NAS provided separately to PIEs which makes difficult to evaluate the impact of the EU Regulation. Last but not least, category (iv), presented as an aggregate number, may mean nothing. The recipients of transparency report do not know what type of services are included in this category, what kinds of clients are served and whether it brings any implications for the future audit contracts.

\section{NAS in the Light of the Big-4 Transparency Reports}

\subsection{Initial Assumptions}

The theoretical analysis of NAS presented so far suggests that NAS are still a disputable area. Let us verify then what conclusions can be reached based on the empirical analysis. For the purpose of such analysis, financial information has been manually collected from transparency reports published for the years: 2017, 2018 and 2019 by the Big-4 firms in twenty-seven EU member states. It has to be emphasised that the financial information, which is the basis for this analysis, relates only to categories (iii) and (iv) mentioned in point 5 , so:

(iii) revenues from permitted non-audit services to entities that are audited by the statutory auditor or the audit firm; and

(iv) revenues from non-audit services to other entities.

The Big-4 firms have been chosen as the most significant and important representatives in the audit sector. The period 2017-2019 has been selected in order to capture changes in NAS in the short term after the formal implementation of the EU reform. Out of initially expected 324 observations, nine have been excluded due to missing data which finally yields 315 observations in total.

Before moving on to the analysis itself and the results, the following remarks should be mentioned:

1) Estimates - despite collecting data with the necessary due care, they should be treated as an estimate only which is used: (i) to understand NAS in a broad picture, (ii) to spot differences and similarities among the EU member states, and (iii) to notice any general changes in terms of the NAS level;

2) Exchange rates - some EU member states belong to the Euro zone and, therefore, report data in Euros whereas other member states present them in their national currencies. In such cases, currency conversion to Euro was necessary. For the purpose of this analysis, the exchange rates as of $31^{\text {st }}$ May 2020 have been applied (Table 2); 
Table 2. Exchange rates as of $31^{\text {st }}$ May 2020

\begin{tabular}{ccc}
\hline & Currency & Units per EUR \\
\hline BGN & Bulgarian Lev & 1,9558 \\
CZK & Czech Koruna & 26,9258 \\
DKK & Danish Krone & 7,4599 \\
HRK & Croatian Kuna & 7,5746 \\
HUF & Hungarian Forint & 346,7104 \\
PLN & Polish Zloty & 4,4468 \\
RON & Romanian Leu & 4,8465 \\
SEK & Swedish Krona & 10,4887 \\
\hline
\end{tabular}

Source: https://www.xe.com/currencytables/?from=EUR\&date=2020-05-31 (accessed $1^{\text {st }}$ July 2020).

3) Data comparability - in general, audit firms presented fees with respect to four categories required by the regulators. However, there were cases when some variations were observed which made difficult to ensure data comparability. What is more, for the purpose of this study, some manual adjustments have been made, e.g., (a) voluntary audits have been manually reclassified from category (iii), (b) assurance services have been reclassified to category (iii) if they were presented together with statutory audits, or (c) fees have been proportionally recalculated when an audit firm changed its business year and reported fees for the period longer than twelve months.

4) The Big-4 firms and their networks - the Big-4 firms usually do not represent only an audit firm but a complex network of firms or separate teams responsible for different consulting services. Therefore, it was not surprising to see that particular firms revealed in their transparency reports revenue streams not only generated by the audit firm itself but also by other firms in the network. However, it often has led to confusion because, despite presenting data in (i)-(iv) categories, it sometimes was difficult to deduce whether the data provided related to the audit firm itself, or to the whole network operating in the particular member state. Similarly, presenting data for "XX Malta", "XX Luxembourg", "a Firm" or "a Company" etc., does not clarify for an external user whether we are taking about an audit firm (which is supposed to be discussed) or about the network. On the contrary, some audit firms decided to publish a table with the financial information but they did not add any narrative. Where possible, data in the Appendices relate to the single audit company.

5) Assurance services and NAS - Once again, information about NAS fees presented in the transparency reports should be treated with the necessary prudence. Categories (iii) and (iv) include not only services which are highly important from the perspective of regulators but include also allowed assurance services which belong to the auditor's "normal" scope of activities.

6.2 Results

In order to present and analyse the collected data, they have been grouped by the EU countries. Each country's dataset includes the NAS fee reported by Deloitte, EY, KPMG, and PWC. To ensure a better comparison between countries, they have been also grouped based on average NAS fee reported in the 2019 transparency reports. Three groups of countries have been then distinguished based on the following criteria:

- Group 1: average NAS fee under EUR10 million (Appendix 1);

- Group 2: average NAS fee between EUR10 and 100 million (Appendix 2); and

- Group 3: average NAS fee over EUR100 million (Appendix 3).

For example, NAS fees reported in Austria in 2019 amount to: EUR30 million (Deloitte), EUR45 million (EY), EUR40 million (KPMG) and EUR19 million (PWC) which gives an average value of EUR 33 million and classifies Austria in Group 2.

\section{Result 1: The level of NAS differs among the EU member states.}

The problem of NAS is usually treated as a problem "embedded" in the audit profession. If we think about possible threats to the auditor independence, the provision of NAS will be probably one of the most frequent answers. However, the analysis of data presented in Appendices 1-3 suggests that the degree of a potential risk differs among the EU member states as the level of NAS is simply different. It is not surprising as countries like Germany or France represent powerful economies with a high GDP and a significant business and financial activity which means a great opportunity 
for audit engagements and the provision of NAS. In such countries, there is also a greater probability of IPOs, mergers, acquisitions, complex international transactions and, thus, a greater demand for potential additional services like tax optimisation or valuation. Therefore, the Big-4 operating in small European countries may be simply limited to the country's economic potential and its development rate. Obviously, the presentation of data is simplistic and it is difficult to imply further conclusions without knowing the particular economy in and out. However, the question for future research might be: Where is the higher risk of a potential opportunistic behaviour in terms of NAS - in the countries with a high NAS level and a great flexibility in accepting NAS contracts or conversely - in the countries where the NAS level is low and each contract matters?

\section{Result 2: NAS fees from audited entities are usually smaller than NAS fees from other clients.}

If we analyse the proportion between NAS fees from audited clients and NAS fees from other clients, it turns out that the first group usually represents less than 50\%. Details have been presented in Table 3. Based on data included in Appendices 1-3, it was possible to calculate and obtain 299 observations. In 239 cases, the share of NAS fees from audited clients was lower than 50\%, i.e., in 44 cases it was below $10 \%$, in 99 cases it was between 10 and 30\%, and in 96 cases between 30 and 50\%. Data might be also read in an opposite way, i.e., the share of NAS fees from other clients was in 239 cases higher than 50\% (in 96 cases between 50 and 70\%, in 99 cases between 70 and $90 \%$, and in 44 cases above $90 \%$ ).

Table 3. Share of NAS fees from audited clients in the period 2017-2019

\begin{tabular}{ccccccc} 
& \multicolumn{4}{c}{ Share of NAS fees from audited clients } & Total no. of observations \\
\hline Group 1 (Appendix 1) & below 10\% & $10-30 \%$ & $30-50 \%$ & above 50\% & Tot \\
Group 2 (Appendix 2) & 6 & 49 & 31 & 26 & 78 \\
Group 3 (Appendix 3) & 16 & 21 & 35 & 16 & 93 \\
Total no. of observations & 44 & 99 & 96 & 60 & 299 \\
\hline
\end{tabular}

Source: Own elaboration.

The results presented in Table 3 may be considered to some extent as optimistic as audited clients are generally provided with NAS at a lower level than other clients. What is more, a part of these permitted NAS relates to allowed assurance services like reviews of a financial statement. However, it does not mean that the situation is perfectly clear. It still remains unknown what the nature of NAS is, especially, in the case of other clients. It is also not entirely clear in multiple cases who provides these services - is it an audit team or a separate advisory team or another audit/consulting firm operating in the network?

\section{Result 3: It is difficult to observe one defined trend in the NAS fees in the period 2017-2019.}

In order to capture trends in NAS fees, the missing observations have been removed from Appendices 1-3 together with the cases when the split between category (iii) and (iv) was not provided. It gave 91 single-firm observations for each year (in total 546 observations in terms of changes between categories). As presented in Table 4, there were Big-4 firms across the EU member states which reported either an increase or a decrease in NAS fees in both categories in the period 2017-2019. Cumulatively, NAS fees increased in the examined population: in 2018 by EUR811 million (9\%) and in 2019 by EUR 25 million $(0.26 \%)$. The most substantial change occurred in 2018 when NAS fees from other clients increased by net EUR 809 million (13\%). However, this strong trend was not confirmed in the following year (in 2019 the analysed fees increased by net EUR 40 million which represented 1\%).

Table 4. Changes in NAS fees in EUR million in the period 2017-2019

\begin{tabular}{|c|c|c|c|c|c|c|c|c|c|c|}
\hline \multirow[b]{2}{*}{$\begin{array}{l}\text { in EUR } \\
\text { million }\end{array}$} & \multicolumn{4}{|c|}{\begin{tabular}{cc}
\multicolumn{2}{c}{ Change 2018/2017 } \\
$\begin{array}{cc}\text { (iii) NAS fees from } & \text { (iv) NAS fees from } \\
\text { audited clients } & \text { other clients }\end{array}$
\end{tabular}} & \multirow[b]{2}{*}{$\begin{array}{c}\text { Total } \\
\text { change }\end{array}$} & \multicolumn{4}{|c|}{\begin{tabular}{cc}
\multicolumn{2}{c}{ Change 2019/2018 } \\
$\begin{array}{cc}\text { (iii) NAS fees from } & \text { (iv) NAS fees from } \\
\text { audited clients } & \text { other clients }\end{array}$
\end{tabular}} & \multirow[b]{2}{*}{$\begin{array}{c}\text { Total } \\
\text { change }\end{array}$} \\
\hline & Increase & Decrease & Increase & Decrease & & Increase & Decrease & Increase & Decrease & \\
\hline $\begin{array}{l}\text { Group 1 } \\
\text { (App. 1) }\end{array}$ & 10 & -42 & 39 & -46 & -39 & 9 & -5 & 26 & -26 & 4 \\
\hline $\begin{array}{l}\text { Group 2 } \\
\text { (App. 2) }\end{array}$ & 47 & -11 & 88 & -8 & 116 & 30 & -50 & 69 & -40 & 9 \\
\hline $\begin{array}{l}\text { Group } 3 \\
\text { (App. 3) }\end{array}$ & 109 & -111 & 742 & -6 & 734 & 163 & -162 & 537 & -526 & 12 \\
\hline $\begin{array}{l}\text { Total } \\
\text { change }\end{array}$ & 166 & -164 & 869 & -60 & 811 & 202 & -217 & 632 & -592 & 25 \\
\hline
\end{tabular}

Source: Own elaboration. 
The level of changes in NAS fees varies between examined groups and it corresponds rather to the level of a business activity in a particular EU member state with the most significant changes in Group 3, especially, in category (iv). However, the data presented in Table 4 show that, in general, there is no single pattern in terms of NAS fees. In some cases fees go up, and in others go down. It may result from the following potential explanations:

- it is possible that NAS are rather one-off services provided on a non-recurring basis. If so, it cannot be guaranteed that clients will need NAS at the same level in the next year;

- it can be assumed that one-off NAS usually relate to substantial advisory contracts like IPOs, mergers or tax advices and again, they are more likely to happen in powerful economies but only in a particular year.

- the Big-4 firms across the EU member states have different business potential and different competitive position in the selected market. Therefore, price rises or falls may also result from the rivalry between the Big-4 firms.

Based on the analysed data, it is difficult to predict any exact NAS patterns in the future. In general, it is not expected to see major permanent changes in category (iii). It should remain rather stable or change proportionally to audit fees as: 1) NAS fees from audited clients include currently assurance-related services which are usually provided together with an audit; 2) audited clients are more under supervision of different authorities so excessive NAS fees could be investigated as a potential threat to the auditor independence; 3) even significant NAS would be rather one-off services than recurring ones.

In terms of category (iv), it seems to be a great revenue opportunity for the Big-4 firms across the EU member states. Unfortunately, it is hard to infer from transparency reports what this category really means and whether the provision of NAS to other clients brings any substantial risks. It is also unknown whether these services mean departure of audit firm's core activities. However, it is expected to see still a significant revenue stream in this category.

\section{Result 4: NAS fees are observed to be higher than audit fees but only in several cases.}

Audit fees are not subject to this analysis, however, they were also collected together with the NAS fees from the transparency reports. It is interesting to verify whether total NAS fees are higher than audit fees at this aggregate level (Table 5). In general, out of 316 observations there were 166 cases (53\%) when NAS fees were higher than audit fees. However, it is worth noticing here that this relationship occurred in 36\% of cases in Group 1, 54\% in Group 2, and $72 \%$ in Group 3.

Table 5. Number of observations when NAS fees were greater than audit fees

\begin{tabular}{lcccc|cc}
\hline & \multicolumn{3}{c|}{ No. of cases meeting criteria: NAS fees > audit fees } & \multicolumn{2}{c}{} \\
& 2017 & 2018 & 2019 & Total & $\%$ & Total no. of cases \\
\hline Group 1 (App. 1) & 18 & 15 & 14 & 47 & $36 \%$ & 130 \\
Group 2 (App. 2) & 14 & 15 & 15 & 44 & $54 \%$ & 82 \\
Group 3 (App. 3) & 26 & 24 & 25 & 75 & $72 \%$ & 104 \\
Total & 58 & 54 & 54 & 166 & $53 \%$ & 316 \\
\hline
\end{tabular}

Source: Source: Own elaboration based on the transparency reports.

Analysis of the data presented in Tables 3-5 suggests a hypothesis that the more developed the economy is, the more significant becomes the category "NAS fees from other clients" as a revenue stream for the Big- 4 firms. It may mean that the Big-4 firms look for a kind of compensation for the recently implemented regulatory restrictions, but it may be also interpreted as an existing demand for specific financial services which the Big-4 firms can simply fulfil. What is more, this area, as being outside the main discussion on a statutory audit, seems not to belong to the regulators' primary interest.

\section{Result 5: Disclosure of NAS fees from PIEs is currently not required.}

The regulators do focus on PIEs, but they did not propose a separate category for PIEs in the NAS presentation. As mentioned earlier, the regulators distinguished only NAS fees from audited entities and from others. During data collection, a few cases have been surprisingly observed when the firms voluntarily disclosed NAS fees from PIEs. This additional category would be beneficial in order to confirm that the audit firms abide by the regulation and do not provide prohibited services to PIEs. Unfortunately, it remains a suggestion for regulators for possible future amendments. 


\section{Conclusions}

The audit reform in Europe was an attempt to introduce "one size fits all" solution among the EU member states. Despite good intentions and the whole discussion about the auditor independence, there are several reasons why the reform may not be considered as totally successful in terms of NAS.

Firstly, the audit reform focuses on the audits carried out in PIEs. This approach is understandable, however, the question arises about services provided to non-PIEs and other entities which are beyond regulators' primary attention. This point is in line with the suggestion raised by Van Liempd, Quick and, Warming-Rasmussen (2019) who indicate a need to expand the strict EU regulations from audits of PIEs into audits of large non-PIEs. Similarly, Clacher, de Ricquebourg, and May (2019) suggest that the definition of PIEs should be revisited in order to include economically important private companies. What is more, the EU regulators allowed derogation in terms of certain tax and valuation services which resulted in member states applying different approaches to the same rules.

Secondly, the regulators provide a closed catalogue of prohibited NAS and it is not controversial that services such as bookkeeping or payroll have been prohibited. The problem occurs in terms of permitted NAS which usually are treated as everything other than a statutory audit. Such approach usually results from differences in NAS disclosures, lack of available data split and specificity of each research study. However, it seems that all NAS should not be evaluated at the same level. For example, assurance or attestation services are different from valuation or tax services. The problem is also highlighted by Ratzinger-Sakel and Schönberger (2015) who state that the role of audit-related services is not clear and the Regulation does not account for them separately. What is more, the results of the studies like Ezzamel, Gwiliam, and Holland (2002) suggest that the perception or strength of particular statistical relationships depend on the NAS type.

Thirdly, there might have been some expectations from transparency reports required by the Regulation. The concept of a transparency report itself is not new, however, the Regulation introduced some changes in terms of retrieval requirements and broader disclosures. Zorio-Grima and Carmona (2019) focus on the content of the transparency reports showing there is a variation in the language used across audit firms and jurisdictions. From the perspective of this study, the most crucial was financial information. The most significant deficiency is the fact that there are only two NAS categories in transparency reports, i.e., NAS fees from audit clients and NAS fees from other clients. Such classification is not sufficient. What really matters is the nature of the NAS offered and whether they are recurring or not (Ahmad, Shafie and Yusof, 2006). Moreover, analysed audit firms sometimes present their interpretation of the reporting requirements and show an additional category or even a different fee breakdown.

The empirical analysis of NAS fees in the EU context shows that the level of NAS differs among the EU member states which may be associated with the country's economic potential and its development. It seems then that opportunities for the NAS provision are not equal everywhere as they vary from EUR400,000 to even EUR1,647 million in extreme cases. It may be also one of the explanations why there is no consensus between the researchers about the consequences of the NAS provision. As there are so large discrepancies between countries, the perception, experience and the effects of NAS provision might be simply different.

As mentioned earlier, there are only two categories of NAS required by the regulators: NAS fees from audited entities and NAS fees from other entities. In $80 \%$ of analysed cases we can observe that the second group is more significant than the first one. NAS fees from other clients currently seem to be a substantial revenue stream for the Big-4 firms, specifically for the countries included in Group 3 (with average NAS fees reported by the Big-4 above EUR100 million). These countries report also higher NAS fees than audit fees in $72 \%$ of the analysed cases. Therefore, it may mean that the Big-4 firms look for a kind of compensation for imposed prohibitions, but it may also indicate an existing demand for specific financial services which the Big-4 firms can simply fulfil. What is more, the area of NAS for other clients, as being outside the main discussion on statutory audit, seems not to belong to regulators' primary interest.

In addition, NAS cumulatively increased in the examined population: in 2018 by EUR811 million (9\%) and in 2019 by EUR25 million (0.26\%). The most substantial change occurred in 2018 when NAS fees from other clients increased by net EUR 809 million (13\%). However, this strong trend was not confirmed in the following year (in 2019 the analysed fees increased by net EUR 40 million which represented 1\%). All these findings confirm the hypothesis, however, the changes vary if we consider the level of each EU member state and each Big-4 firm. At the same time, the empirical findings are not in line with Willekens, Dekeyser and Simac (2019) who explore how the nominal level of NAS fees evolved over the period 2013-2017 and find that the average NAS fee has decreased by 31\% for the Big-4 group and by 9\% for the non-Big-4 firms. Such differences between studies may suggest the probable non-recurring and short-term character of NAS, particular country's economic conditions creating various opportunities for the NAS provision and different competition levels among the Big-4 firms in the EU member states. 
Finally, the study underlines deficiency in proper NAS disclosure and reporting which might be observed also in the case of transparency reports. The reports do not explain the nature of NAS and the reporting requirements do not include a separate category for NAS provided to PIEs. All findings of this study may be another argument for regulators to address the problem of NAS in more detail starting from their advice on a NAS taxonomy which might be used then as a point of reference. It would be also beneficial for researchers exploring the NAS aspect and, thus, may enhance data and results comparability between studies. Additional disclosure requirements like NAS provided to PIEs and a recurring or non-recurring character of NAS would also support the better understanding and evaluation of the consequences of the EU audit reform.

This study is subject to some limitations. First of all, the analysed time frame includes only three years (2017-2019) and it may be too early to completely evaluate the outcome of the audit reform. What is more, this study compares the potential of the Big-4 firms in the EU member states but does not consider country-specific features. Finally, the study concentrates also only on the NAS aspect of the audit reform without taking into account other elements, like mandatory audit rotation and audit tenure.

\section{References}

Accountancy Europe. (2018). Member States'implementation of new EU audit rules. Retrieved from https://www.accountancyeurope.eu/wp-content/uploads/Audit-policy-implementation-state-of-play_April-2018-2.p df

Accountancy Europe. (2019). Member States' implementation of new EU audit rules. Retrieved from https://www.accountancyeurope.eu/wp-content/uploads/Audit-policy-implementation-state-of-play_February-2019 2.pdf

Ahmad, A. C., Shafie, R., \& Yusof, N. Z. M. (2006). The provision of non-audit services, audit fees and auditor independence. Asian Academy of Management Journal of Accounting and Finance, 2(1), 21-40.

Al-Ajmi, J., \& Saudagaran, S. (2011). Perceptions of auditors and financial-statement users regarding auditor independence in Bahrain. Managerial Auditing Journal, 26(2), 130-160. https://doi.org/10.1108/02686901111095010

Al-Hajri, M. O. (2018). The impact of the joint provision of non-audit services on audit firm's tenure: A Kuwaiti evidence, Journal of Applied Business Research, 34(1), 69-80. https://doi.org/10.19030/jabr.v34i1.10093

Ali, M. J., Singh, R. K. S., \& Al-Akra, M. (2018). The impact of audit committee effectiveness on audit fees and non-audit service fees, Accounting Research Journal, 31(2), 174-191. https://doi.org/10.1108/ARJ-11-2015-0144

Al-Sraheen, D. A. D. O. (2019). The role of the audit committee in moderating the negative effect of non-audit services on earnings management among industrial firms listed on the Amman Stock Exchange. Afro-Asian Journal of Finance and Accounting, 9(3), 349-361. https://doi.org/10.1504/AAJFA.2019.100983

Anandarajan, A., Kleinman G., \& Palmon, D. (2012). Is non-audit services a suitable proxy for auditor independence in the post-SOX period?, Research in Accounting Regulation, 24, 105-111.

https://doi.org/10.1016/j.racreg.2012.05.003

Aschauer, E., \& Quick, R. (2018). Mandatory audit firm rotation and prohibition of audit firm-provided tax services: Evidence from investment consultants' perceptions. International Journal of Auditing, 22(2), 131-149. https://doi.org/10.1111/ijau.12109

Bamahros, H. M., \& Wan-Hussin, W. N. (2015). Non-audit services, audit firm tenure and earning management in Malaysia. Asian Academy of Management Journal of Accounting and Finance, 11(1), 145-168. Retrieved from https://core.ac.uk/download/pdf/154383457.pdf

Beattie, V., \& Fearnley, S. (2002). Auditor Independence and Non-Audit Services: A Literature Review. Institute of Chartered Accountants in England \& Wales: London, UK. ISBN 9781841521381

Bell, T. B., Causholli, M., \& Knechel W. R. (2015). Audit Firm Tenure, Non-Audit Services, and Internal Assessments of Audit Quality. Journal of Accounting Research, 53(3), 461-509. https://doi.org/10.1111/1475-679X.12078

Bleibtreu, C., \& Stefani, U. (2012). The Interdependence between Audit Market Structure and the Quality of Financial Reporting: The Case of Non-Audit Services, Working Paper Series 2012-01. Retrieved from http://www.uni-konstanz.de/FuF/wiwi/workingpaperseries/WP_Bleibtreu-Stefani_1-12.pdf

Carmona, P., Momparler, A., \& Lassala, C. (2015). The relationship between non-audit fees and audit quality: dealing with the endogeneity issue. Journal of Service Theory and Practice, 25(6), 777-795.

https://doi.org/10.1108/JSTP-07-2014-0163 
Castillo-Merino, D., Garcia-Blandon, J., \& Martinez-Blasco, M. (2018). Auditor Independence, Current and Future NAS Fees and Audit Quality: Were European Regulators Right? European Accounting Review, 29(2), 233-262. https://doi.org/10.1080/09638180.2019.1577151

Chu, B., \& Hsu, Y. (2018). Non-audit services and audit quality — the effect of Sarbanes-Oxley Act. Asia Pacific Management Review, 23, 201-208. https://doi.org/10.1016/j.apmrv.2017.07.004

Clacher, I., de Ricquebourg, A. D., \& May A. (2019). Who gets all the PIE? Regulation of the statutory audit for private UK companies. Accounting, Auditing \& Accountability Journal, 32(5), 1297-1324. https://doi.org/10.1108/AAAJ-12-2015-2341

Craswell, A. T. (1999). Does the Provision of Non-Audit Services Impair Auditor Independence? International Journal of Auditing, 3, 29-40. https://doi.org/10.1111/1099-1123.00047

De Fuentes, C., \& Pucheta-Martinez, M. C. (2009). Auditor independence, joint determination of audit and non-audit fees and the incidence of qualified audit reports. Academia, Revista Latinoamericana de Administración, 43, 63-92. Retrieved from http://www.redalyc.org/articulo.oa?id=71612112005

DeFond, M. L., Raghunandan, K., \& Subramanyam, K. R. (2002). Do Non-Audit Service Fees Impair Auditor Independence? Evidence from Going Concern Audit Opinions, Journal of Accounting Research, 40(4), 1247-1274. https://doi.org/10.1111/1475-679X.00088

Effiezal, A., Abdul, W., Nik, A., Majid, W. Z., Harymawan, I., \& Agustia, D. (2020). Characteristics of auditors' non-audit services and accruals quality in Malaysia. Pacific Accounting Review, 32(2), 147-175. https://doi.org/10.1108/PAR-10-2018-0072

EU Directive 2014/56/EU. (2014). Retrieved from https://eur-lex.europa.eu/legal-content/EN/TXT/PDF/?uri=CELEX:32014L0056\&from=PL

EU Regulation 537/2014. (2014). Retrieved from https://eur-lex.europa.eu/legal-content/en/TXT/?uri=CELEX:32014R0537

Ezzamel, M., Gwilliam, D. R., \& Holland, K. M. (2002). The Relationship between Categories of Non-Audit Services and Audit Fees: Evidence from UK Companies. International Journal of Auditing, 6, 13-35. https://doi.org/10.1111/j.1099-1123.2002.tb00003.x

Firth, M. (1997). The provision of NAS and the pricing of audit fees. Journal of Business Finance\&Accounting, 24(3) \&(4), 511-525. https://doi.org/10.1111/1468-5957.00118

Flaming, L. J. (2002). Th effect of non-audit services on investor judgments about auditor independence, auditor knowledge, audit quality and investment (Doctoral dissertation, the University of Oklahoma). Retrieved from https://shareok.org/handle/11244/488

Garcia-Blandon, J., Argiles, J. M., \& Ravenda, D. (2020). On the Relationship between Audit Tenure and Fees Paid to the Audit Firm and Audit Quality. Accounting in Europe, 17(1), 78-103. https://doi.org/10.1080/17449480.2019.1669808

Hohenfels, D., \& Quick, R. (2020). Non-audit services and audit quality: evidence from Germany. Review of Managerial Science, 14, 959-1007. https://doi.org/10.1007/s11846-018-0306-z

Horton, J., Tsipouridou, M., \& Wood, A. (2018). European Market Reaction to Audit Reforms. European Accounting Review, 27(5), 991-1023. https://doi.org/10.1080/09638180.2017.1394203

Ianniello, G. (2011). Disclosure of non-audit services in annual reports and auditor independence: Evidence from Italy. International Journal of Disclosure and Governance, 8, 16-30. https://doi.org/10.1057/jdg.2010.17

Ianniello, G. (2015). The effects of board and auditor independence on earnings quality: evidence from Italy. Journal of Management and Governance, 19(1), 229-253. https://doi.org/10.1007/s10997-013-9285-2

ISAE 3000. (2013). International Standard on Assurance Engagements. Retrieved from https://www.ifac.org/system/files/publications/files/ISAE\%203000\%20Revised\%20-\%20for\%20IAASB.pdf

Iyer, G. S., Iyer, V. M., \& Mishra, B. K. (2003). The impact of non-audit service fee disclosure requirements on audit fee and non-audit service fee in the United Kingdom: an empirical analysis. Advances in Accounting, 20, 127-140. https://doi.org/10.1016/S0882-6110(03)20006-7

Kohlbeck, M. J., Brown, V. L., \& Trainor, J. (2010). Did the SOX Ban on Non-Audit Services Go Far Enough or Too Far? Evidence from Investors' Perception of Auditor Independence. https://doi.org/10.2139/ssrn.1620558

Kwak, J. W., \& Park, M. J. (2020). Effect of Auditor's Simultaneous Audit and Tax Services and Tax-service Fee on 
Firm Value: Korea's Evidence. Journal of Asian Finance, Economics and Business, 7(7), 219-228. https://doi.org/10.13106/jafeb.2020.vol7.no7.219

Legoria J., Rosa G., \& Soileau, J. S. (2017). Audit quality across non-audit service fee benchmarks: Evidence from material weakness opinions. Research in Accounting Regulation, 29(2), 97-108. https://doi.org/10.1016/j.racreg.2017.09.001

Lennox, C. S. (1999). Non-audit fees, disclosure and audit quality. European Accounting Review, 8(2), 239-252. https://doi.org/10.1080/096381899336014

Lisic, L. L., Myers, L. A., Pawlewicz, R., \& Seidel, T. A. (2019). Do Accounting Firm Consulting Revenues Affect Audit Quality? Evidence from the Pre- and Post-SOX Eras. Contemporary Accounting Research, 36(2), 1028-1054. https://doi.org/10.1111/1911-3846.12424

Meuwissen, R., \& Quick, R. (2019). The effects of non-audit services on auditor independence. An experimental investigation of supervisory board members' perception. Journal of International Accounting, Auditing and Taxation, 36(2019), 1-14. https://doi.org/10.1016/j.intaccaudtax.2019.05.004

Obeid, A., Obeid, O. A., \& Sundarasen, S. D. (2017). Non-audit services in Sudan: Provision crave or regulation spurn, International Journal of Applied Business and Economic Research, 15(2), 81-94.

Patel, A., Varma, V. S., \& Prasad, P. (2009). Provision of Non-Audit Services, Low Balling, Audit Tenure and Auditor Type. The ICFAI University Journal of Audit Practice, 6(1), 62-70. Retrieved from http://repository.usp.ac.fj/1225/

Ramzan, M., Ahmed, I., \& Rafay, A. (2020). Is Auditor Independence Influenced by Non-Audit Services? A Stakeholder's Viewpoint. Pakistan Journal of Commerce and Social Science, 14(1), 388-408. Retrieved from https://ssrn.com/abstract=3628438

Ratzinger-Sakel, N. V. S., \& Schönberger, M. W. (2015). Restricting Non-Audit Services in Europe - The Potential (Lack of) Impact of a Blacklist and a Fee Cap on Auditor Independence and Audit Quality. Accounting in Europe, 12(1), 61-86. https://doi.org/10.1080/17449480.2015.1035290

Read, W. J. (2015). Auditor fees and Going-Concern Reporting decisions on bankrupt Companies: Additional Evidence, Current Issues in Auditing, 9(1), A13-A27. https://doi.org/10.2308/ciia-51109

Salehi, M., \& Moradi, M. (2010). Iranian Angle on Non-Audit Services: Some Empirical Evidence. Managing Global Transitions. International Research Journal, 8(2), 123-144. Retrieved from http://www.fm-kp.si/en/zalozba/ISSN/1581-6311/8-2.pdf\#page=5

Sori, Z. M., Karbhari, Y., \& Mohamad, S. (2010). Commercialization of Accounting Profession: The Case of Non-audit Services, International Journal of Economics and Management, 4(2), 212-242.

SOX. (2002). The Sarbanes-Oxley Act. Retrieved from https://pcaobus.org/About/History/Documents/PDFs/Sarbanes_Oxley_Act_of_2002.pdf

Tepalagul, N., \& Lin, L. (2015). Auditor Independence and Audit Quality: A Literature Review. Journal of Accounting, Auditing and Finance, 30(1), 101-121. https://doi.org/10.1177/0148558X14544505

Van Liempd, D., Quick R., \& Warming-Rasmussen, B. (2019). Auditor-provided nonaudit services: Post EU-regulation evidence from Denmark. International Journal of Auditing, 23, 1-19. https://doi.org/10.1111/ijau.12131

Wahab, E.A.A., Gist, W.E., \& Majid, W.Z.N.A. (2014). Characteristics of non-audit services and financial restatements in Malaysia. Journal of Contemporary Accounting \& Economics, 10(3), 225-247. https://doi.org/10.1016/j.jcae.2014.10.001

Walker, A., \& Hay D. (2013). Non-audit services and knowledge spillovers: An investigation of the audit report lag. Meditari Accountancy Research, 21(1), 32-51. https://doi.org/10.1108/MEDAR-07-2012-0024

Willekens, M., Dekeyser, S., \& Simac, I. (2019). EU Statutory Audit Reform: Impact on Costs, Concentration and Competition, Study for the Committee on Economic and Monetary Affairs, Policy Department for Economic, Scientific and Quality of Life Policies. Retrieved from https://www.europarl.europa.eu/RegData/etudes/STUD/2019/631057/IPOL_STU(2019)631057_EN.pdf

Wu, C.Y. H., Hsu, H. H., \& Haslam, J. (2016). Audit committees, non-audit services, and auditor reporting decisions prior to failure. The British Accounting Review, 48, 240-256. https://doi.org/10.1016/j.bar.2015.03.001

Zorio-Grima, A., \& Carmona, P. (2019). Narratives of the Big-4 transparency reports: country effects or firm strategy? Managerial Auditing Journal, 34(8), 951-985. https://doi.org/10.1108/MAJ-09-2018-1994 
Appendix 1. Countries with the average NAS fee below EUR 10 million

\begin{tabular}{|c|c|c|c|c|c|c|c|c|c|c|}
\hline \multirow{2}{*}{$\begin{array}{c}\begin{array}{c}\text { in EUR } \\
\text { million }\end{array} \\
\text { Member state } \\
\end{array}$} & \multirow[b]{2}{*}{ Big-4 } & \multicolumn{3}{|c|}{2017} & \multicolumn{3}{|c|}{2018} & \multicolumn{3}{|c|}{2019} \\
\hline & & (iii) & (iv) & TOTAL & (iii) & (iv) & TOTAL & (iii) & (iv) & TOTAL \\
\hline \multirow{4}{*}{$\frac{\frac{\pi}{\sqrt{n}}}{\frac{\pi}{2}}$} & $\mathrm{D}$ & 1.8 & 6.1 & 7.9 & 2.7 & 4.6 & 7.3 & 3.8 & 4.7 & 8.5 \\
\hline & $\mathrm{E}$ & 4.0 & 7.9 & 11.9 & 0.7 & 0.6 & 1.3 & 0.5 & 0.9 & 1.4 \\
\hline & $\mathrm{K}$ & 6.4 & 11.0 & 17.4 & 5.6 & 9.4 & 15.0 & 5.8 & 5.1 & 10.9 \\
\hline & $\mathrm{P}$ & 12.5 & 7.2 & 19.7 & 16.4 & 7.2 & 23.6 & 16.2 & 3.0 & 19.2 \\
\hline \multirow{4}{*}{$\begin{array}{l}\mathscr{d} \\
\stackrel{d}{0}\end{array}$} & $\mathrm{D}$ & 0.5 & 5.1 & 5.6 & 0.6 & 6.5 & 7.1 & 0.9 & 6.3 & 7.2 \\
\hline & $\mathrm{E}$ & 1.3 & 4.4 & 5.7 & 2.6 & 4.8 & 7.4 & 2.2 & 3.2 & 5.4 \\
\hline & $\mathrm{K}$ & 4.5 & 14.4 & 18.9 & 1.6 & 22.7 & 24.3 & 1.0 & 20.6 & 21.6 \\
\hline & $\mathrm{P}$ & 3.3 & 0.8 & 4.1 & 3.4 & 1.9 & 5.3 & 2.8 & 2.5 & 5.3 \\
\hline \multirow{4}{*}{ 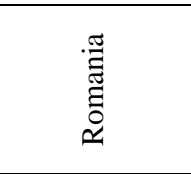 } & $\mathrm{D}$ & 2.6 & 5.7 & 8.3 & 0.6 & 9.2 & 9.8 & 4.1 & 6.8 & 10.9 \\
\hline & $\mathrm{E}$ & 0.5 & 0.2 & 0.7 & 2.5 & 1.0 & 3.5 & 2.6 & 1.4 & 4.0 \\
\hline & $\mathrm{K}$ & & & 12.8 & 6.3 & 1.8 & 8.1 & 6.7 & 1.8 & 8.5 \\
\hline & $\mathrm{P}$ & 3.4 & 5.3 & 8.7 & 2.1 & 2.5 & 4.6 & 2.5 & 5.9 & 8.4 \\
\hline \multirow{4}{*}{ } & $\mathrm{D}$ & 0.1 & 3.9 & 4.0 & 0.031 & 3.6 & 3.6 & 0.03 & 3.0 & 3.0 \\
\hline & $\mathrm{E}$ & 3.8 & 9.4 & 13.2 & 2.9 & 11.6 & 14.5 & 2.6 & 12.1 & 14.7 \\
\hline & $\mathrm{K}$ & 0.5 & 2.2 & 2.7 & 0.5 & 2.9 & 3.4 & 0.5 & 2.4 & 2.9 \\
\hline & $\mathrm{P}$ & 0.5 & 4.4 & 4.9 & 0.7 & 5.4 & 6.1 & 0.6 & 5.6 & 6.2 \\
\hline \multirow{4}{*}{ 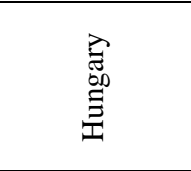 } & $\mathrm{D}$ & 1.3 & 2.4 & 3.7 & 1.0 & 2.2 & 3.2 & 2.4 & 2.2 & 4.6 \\
\hline & E & 1.2 & 1.1 & 2.3 & 1.2 & 1.1 & 2.3 & 1.2 & 1.7 & 2.9 \\
\hline & $\mathrm{K}$ & 3.1 & 7.1 & 10.2 & 0.4 & 8.3 & 8.7 & 0.1 & 10.7 & 10.8 \\
\hline & $\mathrm{P}$ & 2.0 & 3.5 & 5.5 & 0.9 & 5.3 & 6.2 & 1.2 & 6.3 & 7.5 \\
\hline \multirow{4}{*}{ 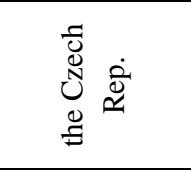 } & $\mathrm{D}$ & 0.5 & 2.3 & 2.8 & 0.3 & 2.9 & 3.2 & 0.2 & 3.3 & 3.5 \\
\hline & $\mathrm{E}$ & 24.6 & 28.3 & 52.9 & 0.8 & 1.6 & 2.4 & 1.3 & 3.2 & 4.5 \\
\hline & $\mathrm{K}$ & 0.8 & 3.3 & 4.1 & 0.8 & 2.8 & 3.6 & 0.3 & 1.2 & 1.5 \\
\hline & $\mathrm{P}$ & 0.6 & 5.1 & 5.7 & 1.3 & 6.7 & 8.0 & 1.5 & 10.2 & 11.7 \\
\hline \multirow{4}{*}{ 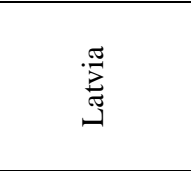 } & $\mathrm{D}$ & 0.003 & 0.1 & 0.1 & 0 & 0.1 & 0.1 & 0.1 & 0.1 & 0.2 \\
\hline & $\mathrm{E}$ & 2.1 & 5.5 & 7.6 & 2.2 & 6.6 & 8.8 & 2.2 & 6.8 & 9.0 \\
\hline & $\mathrm{K}$ & 0.7 & 3.9 & 4.6 & 0.7 & 3.5 & 4.2 & 0.6 & 4.7 & 5.3 \\
\hline & $\mathrm{P}$ & 0.8 & 2.8 & 3.6 & 1.1 & 3.4 & 4.5 & 0.7 & 4.8 & 5.5 \\
\hline \multirow{4}{*}{$\begin{array}{l}\stackrel{\pi}{\overparen{\pi}} \\
\stackrel{0}{0} \\
\dot{U}\end{array}$} & $\mathrm{D}$ & 0.4 & 3.8 & 4.2 & 0.4 & 4.6 & 5.0 & 0.5 & 4.3 & 4.8 \\
\hline & E & 1.4 & 4.1 & 5.5 & 0.9 & 8.3 & 9.2 & 0.1 & 0.6 & 0.7 \\
\hline & $\mathrm{K}$ & 0.5 & 5.5 & 6.0 & 0.5 & 11.8 & 12.3 & 0.3 & 12.3 & 12.6 \\
\hline & $\mathrm{P}$ & 0.7 & 1.4 & 2.1 & 0.1 & 1.5 & 1.6 & 0.3 & 1.4 & 1.7 \\
\hline \multirow{4}{*}{$\begin{array}{l}\stackrel{\pi}{\Xi} \\
\stackrel{0}{0} \\
\text { 至 }\end{array}$} & $\mathrm{D}$ & \multicolumn{3}{|c|}{ file is not available } & \multicolumn{3}{|c|}{ file is not available } & \multicolumn{2}{|c|}{0.4} & 0.4 \\
\hline & $\mathrm{E}$ & 1.2 & 2.8 & 4.0 & 1.2 & 2.6 & 3.8 & 1.2 & 3.3 & 4.5 \\
\hline & $\mathrm{K}$ & 0.5 & 1.2 & 1.7 & 0.7 & 1.5 & 2.2 & 0.7 & 3.5 & 4.2 \\
\hline & $\mathrm{P}$ & 0.7 & 2.2 & 2.9 & 0.7 & 2.8 & 3.5 & 0.9 & 3.6 & 4.5 \\
\hline \multirow{4}{*}{ 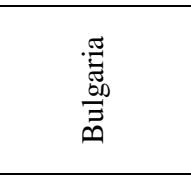 } & $\mathrm{D}$ & 1.1 & 1.0 & 2.1 & 1.1 & 0.9 & 2.0 & 1.1 & 1.5 & 2.6 \\
\hline & $\mathrm{E}$ & 0.5 & 2.7 & 3.2 & 0.2 & 1.5 & 1.7 & 0.3 & 2.1 & 2.4 \\
\hline & $\mathrm{K}$ & 1.4 & 2.5 & 3.9 & 0.7 & 0.1 & 0.8 & 0.8 & 0.3 & 1.1 \\
\hline & $\mathrm{P}$ & 0.3 & 1.3 & 1.6 & 0.3 & 1.2 & 1.5 & 0.4 & 3.6 & 4.0 \\
\hline \multirow{4}{*}{$\begin{array}{l}\frac{\pi}{7} \\
\frac{0}{0} \\
\frac{0}{n}\end{array}$} & $\mathrm{D}$ & 0.7 & 0.7 & 1.4 & 0.8 & 0.6 & 1.4 & 0.7 & 1.0 & 1.7 \\
\hline & $\mathrm{E}$ & 0.8 & 1.9 & 2.7 & 0.3 & 2.1 & 2.4 & 0.8 & 1.6 & 2.4 \\
\hline & $\mathrm{K}$ & 0.5 & 0.3 & 0.8 & 0.4 & 0.1 & 0.5 & 0.4 & 0.4 & 0.8 \\
\hline & $\mathrm{P}$ & 0.5 & 0.5 & 1.0 & 0.2 & 0.6 & 0.8 & 0.4 & 0.2 & 0.6 \\
\hline
\end{tabular}

Abbreviations:

D - Deloitte

$\mathrm{E}-\mathrm{EY}$

$\mathrm{K}-\mathrm{KPMG}$

$\mathrm{P}$ - PWC

(iii) revenues from permitted non-audit services to entities that are audited by the statutory auditor or the audit firm.

(iv) revenues from non-audit services to other entities.

Source: Transparency reports. 
Appendix 2. Countries with the average NAS fee between EUR 10 and 100 million

\begin{tabular}{|c|c|c|c|c|c|c|c|c|c|c|}
\hline \multicolumn{2}{|l|}{$\begin{array}{l}\text { in EUR } \\
\text { million }\end{array}$} & \multicolumn{3}{|c|}{2017} & \multicolumn{3}{|c|}{2018} & \multicolumn{3}{|c|}{2019} \\
\hline Member state & Big-4 & (iii) & (iv) & TOTAL & (iii) & (iv) & TOTAL & (iii) & (iv) & TOTAL \\
\hline \multirow{4}{*}{$\begin{array}{l}\bar{T} \\
\text { Do } \\
\vec{D}_{0}^{0} \\
0\end{array}$} & $\mathrm{D}$ & 12 & 18 & 30 & 9 & 24 & 33 & 9 & 23 & 32 \\
\hline & $\mathrm{E}$ & 1 & 11 & 12 & 1 & 12 & 13 & 4 & 9 & 13 \\
\hline & $\mathrm{K}$ & \multicolumn{2}{|c|}{21} & 21 & \multicolumn{2}{|c|}{25} & 25 & \multicolumn{2}{|c|}{28} & 28 \\
\hline & $\mathrm{P}$ & 14 & 3 & 17 & 15 & 5 & 20 & 8 & 16 & 24 \\
\hline \multirow{4}{*}{$\begin{array}{l}\underset{\Xi}{\Xi} \\
\underset{\Xi}{\Xi}\end{array}$} & $\mathrm{D}$ & 5 & 40 & 45 & 14 & 42 & 56 & 21 & 44 & 65 \\
\hline & $\mathrm{E}$ & 32 & 40 & 72 & 36 & 51 & 87 & 26 & 60 & 86 \\
\hline & $\mathrm{K}$ & 29 & 55 & 84 & 32 & 63 & 95 & 37 & 65 & 102 \\
\hline & $\mathrm{P}$ & 32 & 41 & 73 & 36 & 49 & 85 & 32 & 61 & 93 \\
\hline \multirow{4}{*}{ 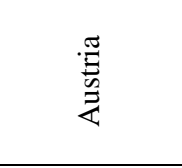 } & $\mathrm{D}$ & 7 & 13 & 20 & 3 & 18 & 21 & 8 & 22 & 30 \\
\hline & $\mathrm{E}$ & 9 & 23 & 32 & 7 & 36 & 42 & 8 & 37 & 45 \\
\hline & $\mathrm{K}$ & 15 & 19 & 34 & 24 & 22 & 46 & 15 & 25 & 40 \\
\hline & $\mathrm{P}$ & 8 & 8 & 16 & 9 & 8 & 17 & 9 & 10 & 19 \\
\hline \multirow{4}{*}{ 总 } & $\mathrm{D}$ & 0 & 16 & 16 & 0 & 18 & 18 & 0 & 22 & 22 \\
\hline & $\mathrm{E}$ & 5 & 5 & 10 & 6 & 7 & 13 & 7 & 9 & 16 \\
\hline & $\mathrm{K}$ & 9 & 8 & 17 & 9 & 12 & 21 & 10 & 15 & 25 \\
\hline & $\mathrm{P}$ & 30 & 26 & 56 & 31 & 29 & 60 & 27 & 35 & 62 \\
\hline \multirow{4}{*}{ 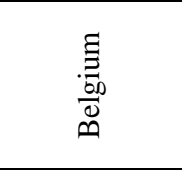 } & $\mathrm{D}$ & & & 91 & 8 & 23 & 31 & 16 & 13 & 29 \\
\hline & $\mathrm{E}$ & \multicolumn{3}{|c|}{ file is not available } & \multicolumn{3}{|c|}{ file is not available } & 14 & 34 & 48 \\
\hline & $\mathrm{K}$ & 4 & 7 & 11 & 6 & 8 & 14 & 5 & 8 & 13 \\
\hline & $\mathrm{P}$ & 6 & 18 & 24 & 8 & 23 & 31 & 10 & 20 & 30 \\
\hline \multirow{4}{*}{$\begin{array}{l}\text { ్ㅠㅇ } \\
\text { 잉 }\end{array}$} & $\mathrm{D}$ & 10 & 6 & 16 & 8 & 6 & 14 & 8 & 7 & 15 \\
\hline & $\mathrm{E}$ & 7 & 21 & 28 & 9 & 15 & 24 & 13 & 15 & 28 \\
\hline & $\mathrm{K}$ & 6 & 2 & 8 & 12 & 0 & 12 & 12 & 1 & 13 \\
\hline & $\mathrm{P}$ & 27 & 38 & 65 & 27 & 39 & 66 & 15 & 16 & 31 \\
\hline \multirow{4}{*}{ 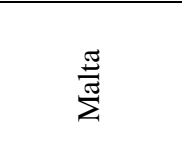 } & $\mathrm{D}$ & 4 & 14 & 18 & 4 & 17 & 21 & 4 & 23 & 27 \\
\hline & $\mathrm{E}$ & 0 & 5 & 5 & 2 & 9 & 11 & 0.5 & 0.5 & 1 \\
\hline & $\mathrm{K}$ & 4 & 9 & 13 & 5 & 10 & 15 & 4 & 12 & 16 \\
\hline & $\mathrm{P}$ & 9 & 11 & 20 & 9 & 12 & 21 & 9 & 14 & 23 \\
\hline
\end{tabular}

Abbreviations:

D - Deloitte

$\mathrm{E}-\mathrm{EY}$

$\mathrm{K}-\mathrm{KPMG}$

$\mathrm{P}-\mathrm{PWC}$

(v) revenues from permitted non-audit services to entities that are audited by the statutory auditor or the audit firm.

(vi) revenues from non-audit services to other entities.

Source: Transparency reports. 
Appendix 3. Countries with the average NAS fee above EUR 100 million

\begin{tabular}{|c|c|c|c|c|c|c|c|c|c|c|}
\hline \multirow{2}{*}{$\begin{array}{l}\text { in EUR } \\
\text { million } \\
\text { Member } \\
\text { state }\end{array}$} & \multirow[b]{2}{*}{ Big-4 } & \multicolumn{3}{|c|}{2017} & \multicolumn{3}{|c|}{2018} & \multicolumn{3}{|c|}{2019} \\
\hline & & (iii) & (iv) & TOTAL & (iii) & (iv) & TOTAL & (iii) & (iv) & TOTAL \\
\hline \multirow{4}{*}{ 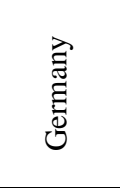 } & $\mathrm{D}$ & \multicolumn{2}{|c|}{641} & 641 & 75 & 757 & 832 & 55 & 819 & 874 \\
\hline & $\mathrm{E}$ & \multicolumn{2}{|c|}{1352} & 1352 & 253 & 1284 & 1537 & 231 & 1416 & 1647 \\
\hline & K & 333 & 794 & 1127 & 378 & 854 & 1232 & 412 & 891 & 1303 \\
\hline & $\mathrm{P}$ & 493 & 896 & 1389 & 487 & 940 & 1427 & 458 & 1092 & 1550 \\
\hline \multirow{4}{*}{ 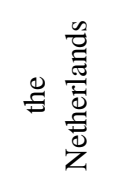 } & $\mathrm{D}$ & 46 & 645 & 691 & 51 & 722 & 773 & 48 & 780 & 828 \\
\hline & $\mathrm{E}$ & 73 & 436 & 509 & 50 & 489 & 539 & 27 & 243 & 270 \\
\hline & $\mathrm{K}$ & 88 & 166 & 254 & 98 & 182 & 280 & 95 & 205 & 300 \\
\hline & $\mathrm{P}$ & 55 & 509 & 564 & 60 & 561 & 621 & 52 & 606 & 658 \\
\hline \multirow{4}{*}{ 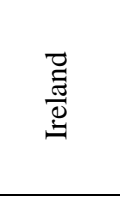 } & $\mathrm{D}$ & \multicolumn{2}{|c|}{184} & 184 & 18 & 226 & 244 & 18 & 212 & 230 \\
\hline & $\mathrm{E}$ & \multicolumn{3}{|c|}{ file is not available } & 51 & 156 & 207 & 83 & 124 & 207 \\
\hline & $\mathrm{K}$ & 96 & 174 & 270 & 87 & 213 & 300 & 60 & 270 & 330 \\
\hline & $\mathrm{P}$ & 47 & 134 & 181 & 52 & 163 & 215 & 64 & 181 & 245 \\
\hline \multirow{4}{*}{ 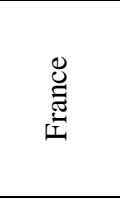 } & $\mathrm{D}$ & \multicolumn{2}{|c|}{25} & 25 & 26 & 23 & 49 & 22 & 20 & 42 \\
\hline & $\mathrm{E}$ & \multicolumn{2}{|c|}{658} & 658 & 40 & 5 & 45 & 40 & 2 & 42 \\
\hline & $\mathrm{K}$ & 27 & 555 & 582 & 32 & 636 & 668 & 30 & 709 & 739 \\
\hline & $\mathrm{P}$ & 35 & 122 & 157 & 29 & 132 & 161 & 23 & 142 & 165 \\
\hline \multirow{4}{*}{ 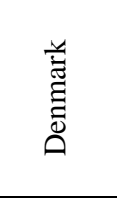 } & $\mathrm{D}$ & \multicolumn{2}{|c|}{298} & 298 & 117 & 229 & 346 & 123 & 270 & 393 \\
\hline & $\mathrm{E}$ & 68 & 70 & 138 & 73 & 75 & 148 & 79 & 89 & 168 \\
\hline & K & 5 & 34 & 39 & 6 & 42 & 48 & 8 & 48 & 56 \\
\hline & $\mathrm{P}$ & 72 & 113 & 185 & 73 & 150 & 223 & 90 & 170 & 260 \\
\hline \multirow{4}{*}{$\begin{array}{l}\text { बै } \\
\bar{d} \\
\vdots \\
\sim\end{array}$} & $\mathrm{D}$ & 29 & 147 & 176 & 18 & 170 & 188 & 64 & 103 & 167 \\
\hline & $\mathrm{E}$ & 89 & 109 & 198 & 94 & 133 & 227 & 87 & 129 & 216 \\
\hline & $\mathrm{K}$ & 69 & 56 & 125 & 72 & 68 & 140 & 67 & 55 & 122 \\
\hline & $\mathrm{P}$ & 116 & 174 & 290 & 131 & 194 & 325 & 89 & 146 & 235 \\
\hline \multirow{4}{*}{ 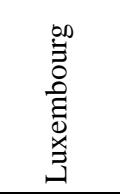 } & $\mathrm{D}$ & & & 221 & 12 & 37 & 49 & 11 & 42 & 53 \\
\hline & $\mathrm{E}$ & \multicolumn{3}{|c|}{ file is not available } & \multicolumn{3}{|c|}{ file is not available } & 11 & 13 & 24 \\
\hline & K & 22 & 119 & 141 & 23 & 129 & 152 & 21 & 141 & 162 \\
\hline & $\mathrm{P}$ & \multicolumn{2}{|c|}{243} & 243 & \multicolumn{3}{|c|}{ data cannot be retrieved } & \multicolumn{2}{|c|}{321} & 321 \\
\hline \multirow{4}{*}{$\begin{array}{l}\Xi \\
\text { ڤ̆ }\end{array}$} & $\mathrm{D}$ & data & 17 ar & vailable & 21 & 73 & 94 & 16 & 65 & 81 \\
\hline & $\mathrm{E}$ & 38 & 122 & 160 & 19 & 160 & 179 & 21 & 53 & 74 \\
\hline & $\mathrm{K}$ & 28 & 16 & 44 & 27 & 18 & 45 & 24 & 25 & 49 \\
\hline & $\mathrm{P}$ & 58 & 33 & 91 & 32 & 52 & 84 & 54 & 59 & 113 \\
\hline & $\mathrm{D}$ & & & 74 & 44 & 27 & 71 & 41 & 24 & 65 \\
\hline 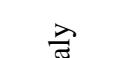 & $\mathrm{E}$ & 70 & 94 & 164 & 70 & 176 & 246 & 66 & 135 & 201 \\
\hline 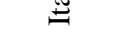 & $\mathrm{K}$ & 62 & 42 & 104 & 53 & 43 & 96 & 73 & 45 & 118 \\
\hline & $\mathrm{P}$ & 55 & 46 & 101 & 59 & 40 & 99 & 61 & 39 & 100 \\
\hline
\end{tabular}

Abbreviations:

D - Deloitte

$\mathrm{E}-\mathrm{EY}$

$\mathrm{K}-\mathrm{KPMG}$

$\mathrm{P}-\mathrm{PWC}$

(vii) revenues from permitted non-audit services to entities that are audited by the statutory auditor or the audit firm.

(viii) revenues from non-audit services to other entities. 
Source: Transparency reports.

\section{Copyrights}

Copyright for this article is retained by the author(s), with first publication rights granted to the journal.

This is an open-access article distributed under the terms and conditions of the Creative Commons Attribution license which permits unrestricted use, distribution, and reproduction in any medium, provided the original work is properly cited. 